\title{
A COMPARISON OF TESTING METHODS FOR DETERMINATION OF SPRAYED CONCRETE TENSILE STRENGTH
}

\author{
MARTIN ZÁVACKÝ \\ Brno University of Technology, Faculty of Civil Engineering, Institute of Geotechnics, Veveři 331/95, 602 00 \\ Brno, Czech Republic \\ correspondence: zavacky.m@fce.vutbr.cz
}

\begin{abstract}
Sprayed concrete is important construction material in tunnelling. Primary lining is essential in NATM where the sprayed concrete can be loaded by tension due to bending moments. The tension is common reason of failure because concrete has a relatively low tensile strength. The tensile strength is usually determined by splitting tensile test in laboratory. However, the results can be distorted because the specimen is not loaded by pure tension in this case. The paper compares results of concrete tensile strength determined by two methods: indirect by the splitting tensile test and direct by the modified tensile test.
\end{abstract}

KEYWORDS: Tensile strength, sprayed concrete, modified tensile test, splitting tensile test.

\section{INTRODUCTION}

Sprayed concrete is an important construction material, especially in underground supporting structures. Thus, knowledge of the mechanical properties of the material is necessary for project design. Unconfined compressive strength is a very common and easily managed testing method. However, tensile strength is also a significant parameter. The tensile strength of concrete is relatively low compared to the compressive one, and therefore failure of the material often occurs through the action of tensile forces.

Direct tensile strength testing comes with several complications such as the requirement of special testing equipment, a high precision in specimen preparation and especially the gripping of a specimen during testing. These identified problems are often overcome by using various indirect tensile testing methods, e.g. a splitting tensile test (STT) or a flexural test. However, indirect methods may result in different values of tensile strength and they often overestimate parameter values [1]. Comprehensive comparative studies have been carried out also in the field of rock mechanics [2, 3]. Thus, direct tensile testing is still important. The modified tension test (MTT) was suggested in order to eliminate the previously stated technical problems 4 and the method has already been well established in practice e.g. at Graz University of Technology [5]. Tension is induced by special geometry of a specimen (Figure 1), therefore a minimal adaptation of the commonly used compression apparatus is needed. The main benefit of the method is the entire elimination of specimen gripping problems.

The main objective of this presentation is to compare the tensile strength of sprayed concrete obtained by two different methods. A series of splitting tensile tests and modified tensile tests were carried out with

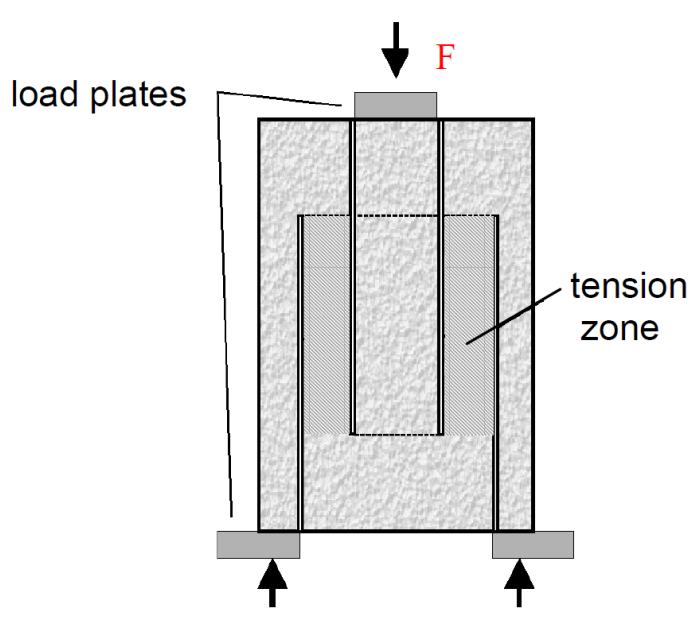

Figure 1. Modified tension test setup [8].

the results showing variation between the methods. The study also extended previous experience of the authors with laboratory testing of sprayed concrete [6], which can be employed for example in the determination of input parameter values for the Shotcrete model [7].

\section{Materials And Methods}

The concrete mixture used for preparation of specimens is described in Table 1. One block of sprayed concrete was used for extraction of all specimens by core drilling (Figure 2). A set of 8 specimens with diameter of $55 \mathrm{~mm}$ and length to diameter ratio 1.0 were used for the splitting tensile test (STT) and a set of 3 specimens for the modified tension test (MTT). The MTT specimens were prepared with an outer diameter of $100 \mathrm{~mm}$ and a length to diameter ratio of 1.5. The inner drilling diameter was $43 \mathrm{~mm}$ and the middle one was $69 \mathrm{~mm}$. The extraction and further 


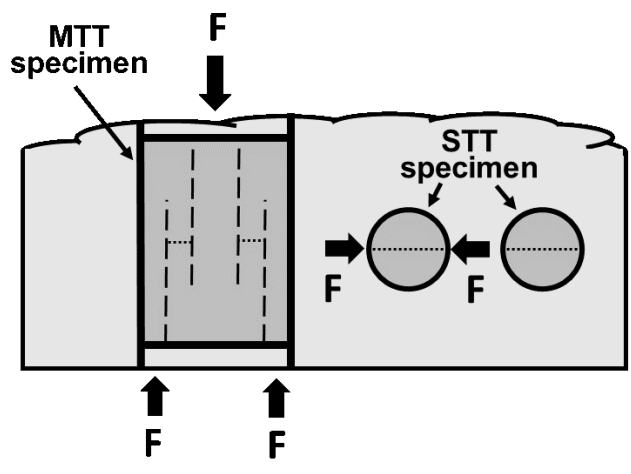

FigURE 2. Scheme of specimens extraction.

loading of the specimens gave attention to orientation of the failure plane. Thus, the failure plane was in all cases parallel to the layering of sprayed concrete.

The tests were carried out by servo-hydraulic compression load frame under load control and a rate of loading $200 \mathrm{~N} / \mathrm{s}$ in both the used methods. The maximal force reached was recorded and tensile strength was calculated according to the following formula:

$$
\sigma_{\mathrm{STT}}=\left(2 F_{\max }\right) /(\pi D L)
$$

for the splitting tensile test, where $F_{\max }$ - maximal force; D - specimen diameter; L - specimen length

$$
\sigma_{\mathrm{MTT}}=F_{\max } /\left(\pi r_{1}^{2}-\pi r_{2}^{2}\right)
$$

for the modified tension test, where there is $F_{\max }$ maximal force; $r_{1}$ - radius of larger core hole (middle drilling); $r_{2}$ - radius of smaller core hole (inner drilling). The dry unit weight of specimens for STT was determined as well, in order to evaluate the material homogeneity. The obtained values of dry unit weight and $\sigma_{\mathrm{STT}}$ for each specimen were assessed by the Kolmogorov-Smirnov test (K-S test) if the data has a normal distribution. The one-sample $\mathrm{K}-\mathrm{S}$ test is a nonparametric test of the equivalence of a continuous probability distribution that can be used to compare a sample with a reference probability distribution [9]:

$$
\begin{array}{r}
D_{\alpha} \geq D_{\mathrm{n}}=\max \left\{\left|F\left(x_{(i)}\right)-(i-1) / n\right|,\right. \\
\left.\left|F\left(x_{(i)}\right)-i / n\right|\right\}, i=1,2, \ldots, n
\end{array}
$$

where there is $D_{\alpha}$ - critical value (significance level $\alpha=0.05$ was used); $\mathrm{F}(\mathrm{x})$ - reference probability distribution (considered as normal distribution); $\mathrm{n}$ - number of samples.

The splitting tensile tests were carried out with respect to testing standard requirements ČSN EN 123906 . The modified tension test procedure was carried out according to suggestions and reported experience published in previous studies $[3,8]$. The tension annulus in the specimens was prepared with a thickness of $13 \mathrm{~mm}$. The maximal aggregate diameter was $8 \mathrm{~mm}$, and hence the obtained tensile strength should not be influenced by oversized aggregates.

\section{RESUlts}

Results of the splitting tensile tests carried out according to the method described in the previous chapter are listed in Table 2. The table contains also data of dry unit weight and statistical parameters as averages and standard deviations. Results of modified tension tests are listed in Table 3.

The dry unit weight (Table 2 showed low variation when the maximal value $\left(2247 \mathrm{~kg} / \mathrm{m}^{3}\right)$ is only $1.3 \%$ above the average and the minimal value $\left(2175 \mathrm{~kg} / \mathrm{m}^{3}\right)$ is only $1.9 \%$ below the average. A standard deviation of $\sigma_{\mathrm{STT}}(0.33 \mathrm{MPa} \rightarrow 8 \%)$ is more significant than in the case of dry unit weight (Table 2). However, both parameters appeared as relatively consistent, and thus the tested material can be considered as homogeneous. Vice-versa, the MTT results showed up as non-consistent, due to a significant drop of tensile strength in the case of specimen 2 (Table 3). Eccentricity of drilling was found by investigation of the specimen after the test (Figure 4). Hence, distribution of load in the specimen was not uniform during the test and concentration of stress probably caused failure under the lower level of loading 3. Therefore, only the results of tests 1 and 3 were considered as valid. In comparison with the STT average, MTT tensile strength was determined as $28 \%$ lower.

Plotting of the cumulative distribution function against data of dry unit weight and STT tensile strength are presented in Figure 3. In both cases Dn value of $K-S$ test was lower than the critical value $\mathrm{D} \alpha$ (see formula 3). Therefore, the normal distribution of the data was judged as appropriate.

\section{Conclusions}

A series of STT and MTT tests were carried out with $28 \%$ higher value of tensile strength by STT. Thus, overestimation of tensile strength by the indirect method was indicated, as was stated in previous studies [3, 8].

The main technical problems of direct tensile testing are eliminated by MTT. However, successful application of the method remains strongly dependent on the precision of specimen preparation. This fact was investigated in 3. and was also observed during the conducted tests (Figure 4). Uncertainty about stress distribution within the geometry of MTT specimens was noted by Molenda [3], and thus additional research from a mechanical point of view would be beneficial.

The experience obtained during the presented experiments may be useful in further laboratory testing of either shotcrete or rocks regarding the purpose of determining input parameter values for various material models used in geotechnical analysis.

\section{ACKNOWLEDGEMENTS}

This paper has been researched and written under the project No. LO1408 "AdMaS UP - Advanced Materials, Structures and Technologies", supported by the Ministry of 


\begin{tabular}{lllll}
\hline Cement & Water/cement ratio & Aggregate 0/1 & Aggregate 0/4 & Aggregate 4/8 \\
\hline $500 \mathrm{~kg} / \mathrm{m}^{3}$ & 0.4 & $174 \mathrm{~kg} / \mathrm{m}^{3}$ & $919 \mathrm{~kg} / \mathrm{m}^{3}$ & $585 \mathrm{~kg} / \mathrm{m}^{3}$ \\
\hline
\end{tabular}

TABLE 1 . Concrete mixture specification.

\begin{tabular}{llll}
\hline Specimen & $\varrho\left[\mathrm{kg} / \mathbf{m}^{3}\right]$ & $\sigma_{\mathrm{STT}}[\mathrm{MPa}]$ & Statistic \\
\hline 1 & 2214 & 3.97 & average $\varrho$ \\
\hline 2 & 2234 & 4.28 & 2217 \\
\hline 3 & 2230 & 4.13 & std $\varrho$ \\
\hline 4 & 2231 & 3.63 & 24 \\
\hline 5 & 2247 & 3.83 & average $\sigma_{\mathrm{STT}}$ \\
\hline 6 & 2218 & 4.38 & 4.15 \\
\hline 7 & 2175 & 4.66 & std $\sigma_{\mathrm{STT}}$ \\
\hline 8 & 2189 & 4.33 & 0.33 \\
\hline
\end{tabular}

TABLE 2. Splitting tensile test and dry unit weight results.

\begin{tabular}{ll}
\hline Specimen & $\sigma_{\mathrm{MTT}}[\mathrm{MPa}]$ \\
\hline 1 & 3.13 \\
\hline 2 & 2.25 \\
\hline 3 & 3.28 \\
\hline Average $(1$ and 3$)$ & 3.21 \\
\hline
\end{tabular}

TABLE 3. Modified tension test results.
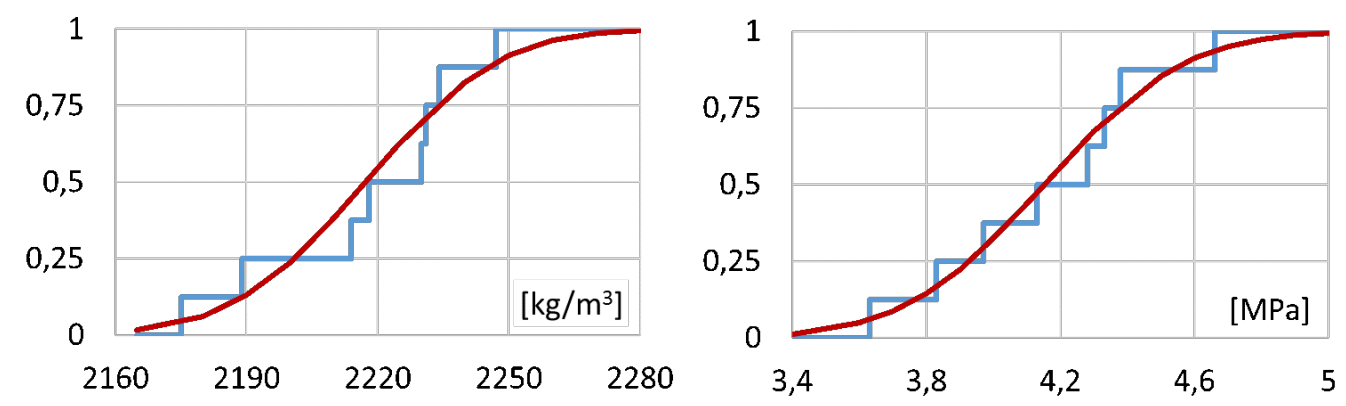

Figure 3. Normal distribution test: Left - dry unit weight; Right - STT tensile strength. Vertical axis represents probability [-]. 


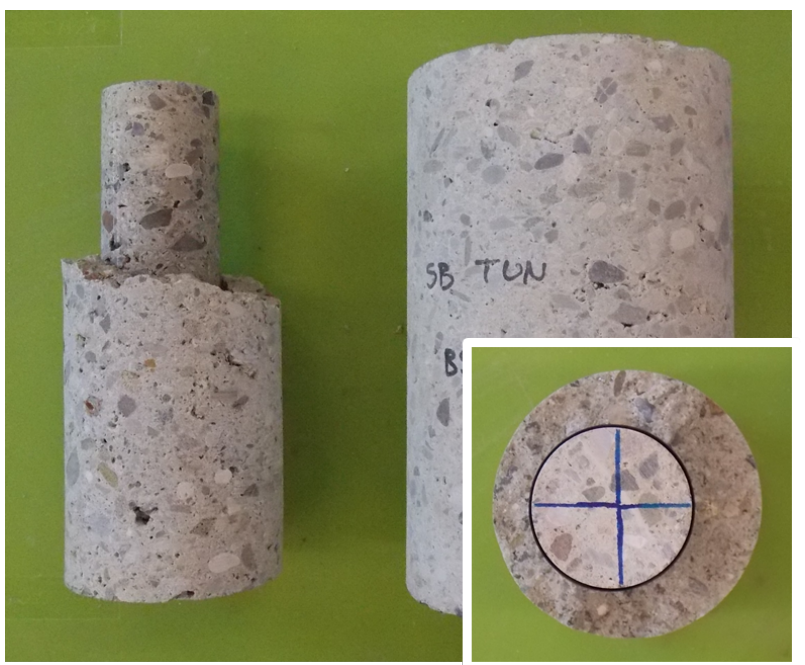

FiguRE 4. Spec. 2 after MTT, detail of eccentricity.

Education, Youth and Sports under the "National Sustainability Programme I" and under the project No. FAST-S18-5356 - "Stanovení vstupních parametrů materiálových modelů pro potřeby podzemního stavitelství s možností využití optimalizačních metod" supported by Brno University of Technology - Faculty of Civil Engineering.

\section{REFERENCES}

[1] S. Kang, J. Park, G. Ryu, et al. Comparison of tensile strengths with different test methods in ultra high strength steel-fiber reinforced concrete. Key

Engineering Materials 417-418:649-652, 2010.
[2] D. Li, L. Wong. The brazilian disc test for rock mechanics applications: Review and new insights. Rock Mechanics and Rock Engineering 46:269-287, 2013.

[3] M. Molenda, F. Stöckhert, S. Brenne, M. Alber. Comparison of hydraulic and conventional tensile strength tests. Effective and Sustainable Hydraulic Fracturing pp. 981-992, 2013.

[4] M. Luong. A new test for tensile strength measurements. Revue Francaise de Géotechnique 34:69-74, 1986.

[5] M. Blümel. Improved procedures for laboratory rock testing. In Proceedings of conference EUROCK 2000. EUROCK, Aachen, Germany, 2000.

[6] M. Závacký, Chalmovský, L. Miča, P. Bílek. Stanovení hodnot vstupních parametrů pokročilého materiálového modelu pro stř́ḱkaný beton. In Proceedings of conference Zakládání staveb. Česká geotechnická společnost ČSSI, 2017.

[7] B. Schädlich, H. Schweiger. A new constitutive model for shotcrete. Numerical Methods in Geotechnical Engineering pp. 103-108, 2014.

[8] R. Plinninger, B. Thomée. Experimental and model studies on the modified tension test $(\mathrm{mtt})$ - a new and simple testing method for direct tension tests. In Proceedings of conference on GeoTechnical Measurements and Modelling. A.A. Balmeka publishers, 2003.

[9] Kolmogorov-smirnov test. https://en.wikipedia. org/wiki/Kolmogorov-Smirnov_test 